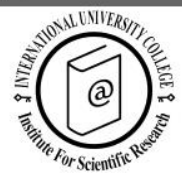

\title{
Can stressful events affect our tourism consumption? Empirical results of preliminary focus group analysis to student groups in Greece with the use of a life stress inventory model.
}

\author{
Anestis K. Fotiadis ${ }^{1 *}$, Chris A. Vassiliadis ${ }^{2}$ and Andreas Adronikidis ${ }^{3}$
}

Received: 10/10/2013 Accepted: 24/04/2014

\begin{abstract}
1 Assistant Professor, I-Shou University, Department of Entertainment and Management, No.1, Sec. 1, Syuecheng Rd., Dashu District, Kaohsiung City 84001, Taiwan, Tel: +886 975255302, E-mail: anesfottiadis@isu.edu.tw

2 Associate Professor, University of Macedonia, Department of Business Administration, Egnatia str. 156, 540 06 Thessaloniki, Greece, Tel: +30 2310891581, E-mail: chris@uom.gr

${ }^{3}$ Associate Professor, University of Macedonia, Department of Business Administration, Egnatia str. 156, 540 06 Thessaloniki, Greece, Tel: +30 2310891581, E-mail: a.andronikidis@uom.edu.gr

* Corresponding author
\end{abstract}

\begin{abstract}
Different research studies argue that external circumstances or events can have an effect on people, but this effect is mediated by the individual's perceptions, capacities, and understanding. While in behavioural and social studies stress research is a well-known traditional research topic, in marketing and tourism studies consumer stress research has been ignored by marketing and consumer researchers. This preliminary research paper examines the result of a consumer stress measurement combination study that includes the use of Social Readjustment Rating Scale and the use of a "trend to buy" research study. Our research question is based on the statement "unique stress events can affect the buying behaviour of different consumer tourist groups". The study is based on three "focus group" organised studies with 26 students, i.e., 9 with graduated, 9 with postgraduated and 8 with post-graduated executives. The results of the study give useful suggestions for the construction of an alternative consumer measurement tool. Finally the paper concludes that the "Death of a relative" is the most important and unique stress life events for the three student groups. When such event occurs, then all the student groups trend not to buy products and services related with their animation and outgoing.
\end{abstract}

(C) 2015 International University College. All rights reserved

Keywords: Social Readjustment Rating Scale; Stress; Consumer Behaviour; Marketing

Citation: Fotiadis, A., Vassiliadis, C. and Adronikidis, A. (2015). Can stressful events affect our tourism consumption? Empirical results of preliminary focus group analysis to student groups in Greece with the use of a life stress inventory model. European Journal of Tourism Research 9, pp. 57-66

\section{Introduction}

Day by day stress influences and determines the lives of modern people, and as a result it preoccupies the academic community more and more. Despite the fact that the concept of stress and the research around this gathers 
Can stressful events affect our tourism consumption? Empirical results of preliminary focus group analysis to student groups in Greece with the use of a life stress inventory model.

more and more attention to the social sciences and behavioural sciences, it has been almost ignored in the field of marketing and particularly of tourism and little has been done to examine and to connect the role of stress with the behaviour of future consumers of tourist services. For example, an unfortunate event such as death may create the need for a consumer to go on a trip. Houge Mackenzie and Kerr (2013), suggest that stress should be more thoroughly examined related to tourism and consumer behaviour. Several tourism academic researchers examine the effect of stress (Ellenberg, Setiawan, Cree, Houston, \& Seddon, 2007; Law, Pearce, \& Woods, 1995; Maréchal et al., 2011; Romero \& Wikelski, 2002) but none of them examine it in relation to stressful events and tourism customer consumption.

The aim of this paper is to study the connection of stress, caused by the various events of life contained in the Social Readjustment Rating Scale of Holmes and Rahe (1967), with the general consumer behaviour by focusing on the possible modification of the tourist behaviour of students of the University of Macedonia. For the carrying out of the research, in the first phase and based on literature, the facts a new amended scale social transformation would have included were established, which should be compatible with the characteristics of the sample and the values of Greek society.

\section{Literature Review}

The term stress is derived from the verb áyx $\omega$ (anho), which in ancient Greek means choke or smother. Stress is an unpleasant feeling, which appears in situations where the person is in danger or is facing a problem and more generally when confronted with a difficult situation. Stress can be of psychogenic origin or may be a consequence of some physical disorder. In addition, it depends on the cognitive and emotional processes, the lifestyle of the individual and its way of thinking. Each person experiences a certain level of anxiety, which is considered normal under certain circumstances. In some other cases, however, increased anxiety, can do harm and contributes to the person's malfunction in activities and it can adversely affect its health.
On the other hand, the consumer's behaviour is the study of how, where, when and why people buy or do not buy a product. It combines elements from psychology, sociology, social anthropology and economics (Fotiadis, Vassiliadis, \& Piper, 2013; Fotiadis, Vassiliadis \& Rekleitis, 2013; Kamenidou, Mamalis, \& Priporas, 2009; Kamenidou \& Priporas, 2010). It tries to understand the decision-making process of purchasers both individually and in groups. It studies the characteristics of individual consumers, such as the demographic and behavioural variables, in an attempt to understand of their wishes (Vassiliadis, Priporas, \& Andronikidis, 2013). It also tries to assess the influences the consumer experiences from various groups, such as family, friends and society in general.

In almost every moment of his life, the modern man adopts a form of consumer behaviour. By watching an advertisement on TV, commenting with friends on a movie that we have seen recently, buying a new $C D$, or even throwing away an old pair of shoes, we behave as consumers. In particular, Statt (1997) argues that the act of consumption is an integral part of our everyday life.

The term consumer behaviour normally refers to any human behaviour intended to purchase products and services. Various definitions have been formulated for the consumer behaviour. According to Narayan and Prasad (2008) and Blackwell, Miniard, and Engel (2006), the consumer behaviour is a multidisciplinary science which not only studies the decisionmaking process and the actual purchase of the product, but also the further activities of the consumer after the purchase of the product, such as use, evaluation and disposal of the product or service. The American Marketing Association defines, on the other hand, the consumer behaviour as "the dynamic interaction of sentiment, of knowledge, of behavior and of the environment through which people carry out transactions in their lives". What applies generally is: Consumer behaviour = Psychology + Marketing

These are social psychology and cognitive psychology. Social psychology is the study of the way in which the personality, attitudes, 
motivation and behaviour of the person are affected by the social groups (Reis, 2001). Cognitive psychology, on the other hand, is the study of all knowledge related to psychological behaviour. Attention, perception, memory/understanding and decision making are the aspects of cognitive psychology which play a key role in consumer behaviour (Gibson, 1984).

The consumer behaviour includes therefore much more than the way in which someone buys tangible products. It is the way in which consumers use services, activities and ideas, such as for example when they go to the doctor, visit a museum, take a trip, read a book, etc. One factor that may influence consumer behaviour is stress. Moschis (2007) p. 430 noted "that the concept of stress received little attention in the field of Marketing". The research projects associating the stress of the consumers with the act of consuming product types are very few. The research approach of stress can be of interest to the cognitive object of Marketing. Thematic areas of examination such as a. consumer behaviour and the way of coping with stressful situations through the procedure of consuming goods, i.e. consuming periodic press aiming at their satisfaction $b$. the tendency to consume great amounts of goods in order to escape from the consequences of an event or a situation that brings forth stress i.e. cinema, apparel, outing with friends. The ways of consumers overcoming these situations can be categorized into the upcoming units of behaviour actions, the approach strategies, and the avoidance strategies, which can involve both the phase of obtaining goods as well as the phase of consuming it (Fotiadis \& Vassiliadis, 2010; Mick \& Fournier, 1998).

While studies suggest that consumers are resorting to a variety of activities to reduce stress, only two attempted to develop a classification of consumer behaviours as coping strategies of stress. Mick and Fournier (1998) research, considers the behaviours with which consumers handle decisions or strategies addressing either avoidance associated with preceding the acquisition and the stage of consumption. This approach excludes non-consumption strategies, which consumers use to cope with the stress caused by consumption. In contrast, the study of Duhachek (2005) identifies non-consumption coping strategies, but this approach does not highlight specific consumer behaviours addressed in the preliminary stage of the decision-making process.

The references related to Marketing and stress are also referred to approach strategies, which the consumers use to cope with stress caused by consumption (Anil, Moschis, \& Euehun, 1999; Duhachek, 2005). In these studies the researchers assume that the consumer reactions and the approach methods they adopt follow the situations that are connected to the consuming of goods. This assumption can therefore not be applicable in the case where the stress has been caused by situations and events of non-consuming type. In other words, the non-consuming type events and situations can and influence outside the procedure of the purchasing decisions the consumer follows, a procedure that also influences and can induce stressful situations to the consumers. Finally, as already mentioned, the consumer reactions are based on two strategies, one of avoidance and the other of approach. The first, by nature, embody greater levels of uncertainty and can cause reduction of a person's self-confidence, however when they achieve what they aim at, they contribute equally importantly to the reduction of stress caused by consuming goods. A widely known tool for the analysis research of stress is the Social Readjustment Rating Scale by Thomas Holmes and Richard Rahe (1967). Holmes and Rahe (1967) note that both the positive as well as the negative events can induce stressful situations to people, since people become stressed on any event which can bring them through change from the present stable situation of their lifestyle and therefore a level of inner readjustment is required (Readjustment) which these people will have to manage. The researchers focused as psychiatrists to the construction of a standardized measurement scale that involves a series of 43 causes (events and situations) of stress that affect the psychosomatic health of these people. The research until the presentation of the model measuring the situations of stress focused on 
Can stressful events affect our tourism consumption? Empirical results of preliminary focus group analysis to student groups in Greece with the use of a life stress inventory model.

matters of number appearance from events and on the categorization and identification of their types. The measurement scale the researchers suggested for the first time favored the procedure of measuring the extent of stress caused by the experiences of situations and events the people have during their life. The methodology was based on the assumption that the stress ratings from the measurement tool could relate to the health status of the people and measure the possibility of illness. The scale remains until nowadays especially timely to the behavioural sciences and the use of scales measuring stress is still a significant point of research interest (Cohen, Kamarck, \& R., 1983; Fouquereau, Fernandez, Muller, \& Sorum, 2003; Haatainen et al., 2003). The use of specialised measurement tools like the student stress scale «The Student Stress Scale», form an adaptation of Holmes and Rahe's Life Events Scale for college-age adults, provides a rough indication of stress levels and possible health consequences (Mullen \& Gerald, 1981).

\section{Concept and scope of the research}

The Marketing strategies are based on the good knowledge of the consumer needs and desires which obviously require beforehand a better knowledge of the procedures for taking purchasing decisions regarding the market segments that interest us. The analysis of the factors that create trends or suspensions in purchasing certain goods obviously forms a useful element of describing the procedures of purchasing decisions the consumers follow and therefore an element of examination in the case of the cognitive project of the Consumer Behaviour (Fotiadis, Huan, \& Costantino, 2013; Hawkins, Best, \& Coney, 2001). The analysis of stress can provide us with useful information through the tools measuring the adjustment level meaning the expected effort they realize they have to make in order to achieve the necessary change of their lifestyle while the analysis of the trend regarding the consumption of goods chosen during the appearance of stress can reinforce the effort for understanding better the consumer behaviour. Aiming at the better description of the influences caused by the events and situations of life to their purchasing behaviour, the opinions of 26 undergraduate and postgraduate students are analyzed in the present research by using the social readjustment scale like other researchers did (Blasco-Fontecilla et al., 2012; Delgado-Gomez, Blasco-Fontecilla, Sukno, Socorro Ramos-Plasencia, \& Baca-Garcia, 2012; Diniz, Schor, \& Blay, 2006; Ngai \& Chan, 2011).

\section{Research questions}

Q1. Which events do the students think that cause them stress based on the effort they make for social readjustment?

Q2. During the appearance of such an event which products are avoided and which are consumed?

Q3. What is the effect on these events on traveling consumption?

\section{Methodology}

After the relevant literature review and after focusing on two scales of social readjustment, a. the general one by Holmes and Rahe (1967) but also the specific ones for students $b$. the one by Mullen and Gerald (1981) a short conversation followed with in depth interviews with 3 undergraduate and postgraduate students. This procedure ended in bringing forth 15 important events, which could be considered as stress sources.

\section{Sample of the study}

Later on, there was a structured procedure of approaching three focus groups which consisted of 9 undergraduate students, 9 postgraduate students with limited or no work experience and 9 postgraduate students with increased work experience and family obligations. The men in the analysis sample were 13 (4 MBA executives, 5 MBA, 4 undergraduate) and the women were also 13 (4 MBA executives, 4 MBA, 5 undergraduate). From 20-22 years old were 9 undergraduate students, 24-29 were the 9 MBA students, 3139 were 6 MBA executive students and 40-45 were 2 MBA executive students. From the 7 married people 5 were married with no kids while 2 were married with kids and 19 people were single. All the students were active students or had graduated from a higher education institution (case of postgraduate students). (Table 1) 
Fotiadis, A., Vassiliadis, C. and Adronikidis, A. (2015) / European Journal of Tourism Research 9, pp. 57-66

Table 1. Sample characteristics

\begin{tabular}{llcccc}
\hline Characteristics & Categories & $\begin{array}{c}\text { MBA executive } \\
\text { students }\end{array}$ & MBA students & Undergraduate & Total \\
\hline Gender & Male & 4 & 5 & 4 & 13 \\
& Female & 4 & 4 & 5 & 13 \\
\multirow{5}{*}{ Age category } & 8 & 9 & 9 & 26 \\
& Total & & & & 9 \\
& $24-23$ years & 0 & 0 & 0 & 9 \\
& $24-30$ & 0 & 9 & 0 & 6 \\
\multirow{5}{*}{ Marital status } & 6 & 0 & 0 & 26 \\
& To-45 & 2 & 0 & 9 & 7 \\
& Motal & 8 & 9 & 0 & 19 \\
& Married & 7 & 0 & 9 & 26 \\
& Non-married & 1 & 9 & 9 & 2 \\
& Total & 8 & 9 & 0 & 24 \\
& With children & 2 & 0 & 9 & 26 \\
\hline
\end{tabular}

\section{Measurement}

The measurement took place during the fall semester 2010-2011 for all three focus groups and it was conducted in different rooms of the academic institution where the students were studying. The participating volunteers as mentioned in the previous paragraph were chosen by the researchers after they had previously been informed on the research procedure. The students were given a readjustment list of 15 events which were included in a questionnaire where the first page was explanatory and was about the way of completing the questionnaire and the purpose of the research while besides the events and the readjustment rating there were also questions concerning the products and services consumed by the students more often during the readjustment period, which followed after the appearance of a very important event as they were presented in the questionnaire. In the second part of the questionnaire demographic information (sex, age, family status, education level) were also included. The interview procedure was of short duration from 45 minutes to a maximum duration of 90 minutes, as an assistance the people being questioned were distributed a description of the research in text as well as the questionnaire to be completed while at the same time the conversations were recorded by the researcher. Finally, there was a recording of the total answers by the researcher on a special answering submission form.

\section{Analysis}

The analysis of the quantitative indicators and the demographics was performed on a submission form by using the Excel@ software. The students' answers were combined and categorized in units of events and consuming products and avoidance.

\section{Stressful Situations and life events}

The final results of the quantitative analysis researching the consumers' readjustment rate by stress-provoking events and the consuming goods trends are presented in table 2 .

As we can see in table 2, most of the respondents said that the event which affect mainly their consumption is: "death of a close family member $(80.20 \%)$ ". So according to our sample when this event occurs costumers consume more cigarettes, alcohol, flowers or food. At the same time when this sad event happens they travel less and they entertain themselves less. Pregnancy also affects positively buying attitude since usually they buy more staff related with the kid and affect negatively cigarettes and alcohol consumption. According to the questioned people it doesn't 
Can stressful events affect our tourism consumption? Empirical results of preliminary focus group analysis to student groups in Greece with the use of a life stress inventory model.

Table 2. Measurement of 15 stressful situations and life events

\begin{tabular}{|c|c|c|c|c|c|}
\hline Place & Life event & $\begin{array}{l}\text { Total } \\
\text { score }\left({ }^{*}\right)\end{array}$ & $\begin{array}{l}\text { No } \\
\%\end{array}$ & Items they consume & What they didn't consume \\
\hline 1 & $\begin{array}{l}\text { Death of a } \\
\text { close family } \\
\text { member }\end{array}$ & 20200 & $\begin{array}{l}21 \\
80.8 \%\end{array}$ & $\begin{array}{l}\text { Cigarettes } \\
\text { Alcohol } \\
\text { Tissues } \\
\text { Inland Revenue, land registry, } \\
\text { Municipality } \\
\text { Churches } \\
\text { I do not consume/no product } \\
\text { I seat in for a time interval } \\
\text { Flowers } \\
\text { Hoop of funeral } \\
\text { Food }\end{array}$ & $\begin{array}{l}\text { I do not go out for amusement } \\
\text { Restriction in products and } \\
\text { services that were previously } \\
\text { consumed } \\
\text { Cinema } \\
\text { Travels } \\
\text { Food } \\
\text { Clothes }\end{array}$ \\
\hline 2 & Pregnancy & 12900 & $\begin{array}{l}17 \\
65.4 \%\end{array}$ & $\begin{array}{l}\text { Visit gynaecologist } \\
\text { Different goods for the baby } \\
\text { (e.g., bed, park, clothes) } \\
\text { Food } \\
\text { Clothes } \\
\text { Amusement }\end{array}$ & $\begin{array}{l}\text { Going out } \\
\text { Fattening food } \\
\text { Hair dyes } \\
\text { Pads } \\
\text { Smoking } \\
\text { Alcohol }\end{array}$ \\
\hline 3 & $\begin{array}{l}\text { Major } \\
\text { personal } \\
\text { injury or } \\
\text { illness }\end{array}$ & 11500 & $\begin{array}{l}11 \\
42.3 \%\end{array}$ & $\begin{array}{l}\text { Medico-pharmaceutical care } \\
\text { Nursing } \\
\text { Communication with relatives } \\
\text { \& friends (telephone) } \\
\text { Gymnastics - physiotherapy } \\
\text { Alcohol } \\
\text { DVD - Books }\end{array}$ & $\begin{array}{l}\text { Alcohol } \\
\text { Cigarettes } \\
\text { Junk food } \\
\text { Restaurants } \\
\text { Travels } \\
\text { Gymnastics } \\
\text { Driving }\end{array}$ \\
\hline 4 & $\begin{array}{l}\text { Separation } \\
\text { with mate }\end{array}$ & 9650 & $\begin{array}{l}14 \\
53.8 \%\end{array}$ & $\begin{array}{l}\text { Fast food, } \\
\text { Luxury products } \\
\text { Alcohol } \\
\text { Going out } \\
\text { Cigarettes } \\
\text { Clothes } \\
\text { Travels } \\
\text { Candies } \\
\text { Hairdresser's } \\
\text { Gym }\end{array}$ & $\begin{array}{l}\text { Alcohol } \\
\text { Super market } \\
\text { Mobile telephone } \\
\text { Credit card loans per month }\end{array}$ \\
\hline 5 & $\begin{array}{l}\text { Change in } \\
\text { financial } \\
\text { status }\end{array}$ & 8650 & $\begin{array}{l}15 \\
57.7 \%\end{array}$ & $\begin{array}{l}\text { Travels } \\
\text { Buying or restriction of } \\
\text { purchasing product \& } \\
\text { services } \\
\text { Purchasing a car } \\
\text { Clothes }\end{array}$ & $\begin{array}{l}\text { Going out at night } \\
\text { Coffee } \\
\text { Clothes } \\
\text { Luxury products } \\
\text { Purchasing a car } \\
\text { Reduction of demand of unnece- } \\
\text { ssary consuming products } \\
\text { Buying only the basic commo- } \\
\text { dities (bread, milk, legumes, } \\
\text { meat, fruits, vegetables) } \\
\text { Travels }\end{array}$ \\
\hline 6 & $\begin{array}{l}\text { Increased } \\
\text { workload at } \\
\text { school/ } \\
\text { university }\end{array}$ & 8150 & $\begin{array}{l}14 \\
53.8 \%\end{array}$ & $\begin{array}{l}\text { Food } \\
\text { Chocolates } \\
\text { Gadgets } \\
\text { Cigarettes } \\
\text { Internet } \\
\text { Stationeries, books, } \\
\text { foodstuffs } \\
\text { Alcohol } \\
\text { Coffee }\end{array}$ & $\begin{array}{l}\text { Diet } \\
\text { Alcohol }\end{array}$ \\
\hline
\end{tabular}


Fotiadis, A., Vassiliadis, C. and Adronikidis, A. (2015) / European Journal of Tourism Research 9, pp. 57-66

\begin{tabular}{|c|c|c|c|c|c|}
\hline 7 & $\begin{array}{l}\text { Being fired } \\
\text { from a job }\end{array}$ & 7720 & $\begin{array}{l}11 \\
42.3 \%\end{array}$ & $\begin{array}{l}\text { Buying newspapers and } \\
\text { reading announcements } \\
\text { More frequent internet use } \\
\text { Alcohol } \\
\text { Travel for recreation }\end{array}$ & $\begin{array}{l}\text { Clothes } \\
\text { Going out } \\
\text { Reduction of buying luxury } \\
\text { products and entertainment } \\
\text { services } \\
\text { Coffees } \\
\text { Clothing } \\
\text { Traveling }\end{array}$ \\
\hline 8 & $\begin{array}{l}\text { Death of a } \\
\text { close friend }\end{array}$ & 7150 & $\begin{array}{l}8 \\
30.8 \%\end{array}$ & $\begin{array}{l}\text { Alcohol } \\
\text { Cigarettes } \\
\text { Travels } \\
\text { Tissues }\end{array}$ & $\begin{array}{l}\text { Cinema } \\
\text { Clubing } \\
\text { Amusement } \\
\text { Food }\end{array}$ \\
\hline 9 & $\begin{array}{l}\text { New girl- or } \\
\text { boyfriend }\end{array}$ & 6500 & $\begin{array}{l}14 \\
53.8 \%\end{array}$ & $\begin{array}{l}\text { Candies } \\
\text { Chocolates } \\
\text { Ice-cream } \\
\text { Gifts } \\
\text { Increase of telephone account } \\
\text { Clothes } \\
\text { Coffee } \\
\text { Drinks } \\
\text { DVD } \\
\text { Cinema } \\
\text { Travels } \\
\text { Condoms }\end{array}$ & $\begin{array}{l}\text { Candies } \\
\text { Food }\end{array}$ \\
\hline 10 & $\begin{array}{l}\text { Outstanding } \\
\text { personal } \\
\text { achievement }\end{array}$ & 5500 & $\begin{array}{l}11 \\
42.3 \%\end{array}$ & $\begin{array}{l}\text { Purchase of clothes } \\
\text { Travel } \\
\text { Amusement } \\
\text { Footware } \\
\text { Food }\end{array}$ & \\
\hline 11 & Jail term & 5100 & $\begin{array}{l}6 \\
23.1 \%\end{array}$ & $\begin{array}{l}\text { Alcohol } \\
\text { Food } \\
\text { Cigarettes }\end{array}$ & $\begin{array}{l}\text { Amusement in Clubs \& Café } \\
\text { Cinema }\end{array}$ \\
\hline 12 & Marriage & 4900 & $\begin{array}{l}11 \\
42.3 \%\end{array}$ & $\begin{array}{l}\text { Luxurious gifts } \\
\text { Cooking goods } \\
\text { Glassware } \\
\text { Gadgets } \\
\text { Travels } \\
\text { Going out } \\
\text { Drink } \\
\text { Food } \\
\text { Clothes - wedding dress } \\
\text { Invitation cards }\end{array}$ & $\begin{array}{l}\text { Reduction of nightlife } \\
\text { Reduction of drinking alcohol } \\
\text { Condoms }\end{array}$ \\
\hline 13 & $\begin{array}{l}\text { Divorce } \\
\text { between } \\
\text { parents }\end{array}$ & 4500 & $\begin{array}{l}6 \\
23.1 \%\end{array}$ & $\begin{array}{l}\text { Courts } \\
\text { Lawyer } \\
\text { Diet } \\
\text { Alcohol } \\
\text { Food }\end{array}$ & \\
\hline 14 & $\begin{array}{l}\text { Failing an } \\
\text { important } \\
\text { course }\end{array}$ & 3370 & $\begin{array}{l}6 \\
23.1 \%\end{array}$ & $\begin{array}{l}\text { Tuition centre } \\
\text { Alcohol } \\
\text { Food } \\
\text { Cigarettes } \\
\text { Coffee }\end{array}$ & Amusement \\
\hline 15 & Sex problems & 3300 & $\begin{array}{l}7 \\
26.9 \%\end{array}$ & $\begin{array}{l}\text { Drugs } \\
\text { Medical help } \\
\text { Sex shop products and } \\
\text { services } \\
\text { Viagra }\end{array}$ & Condoms \\
\hline
\end{tabular}




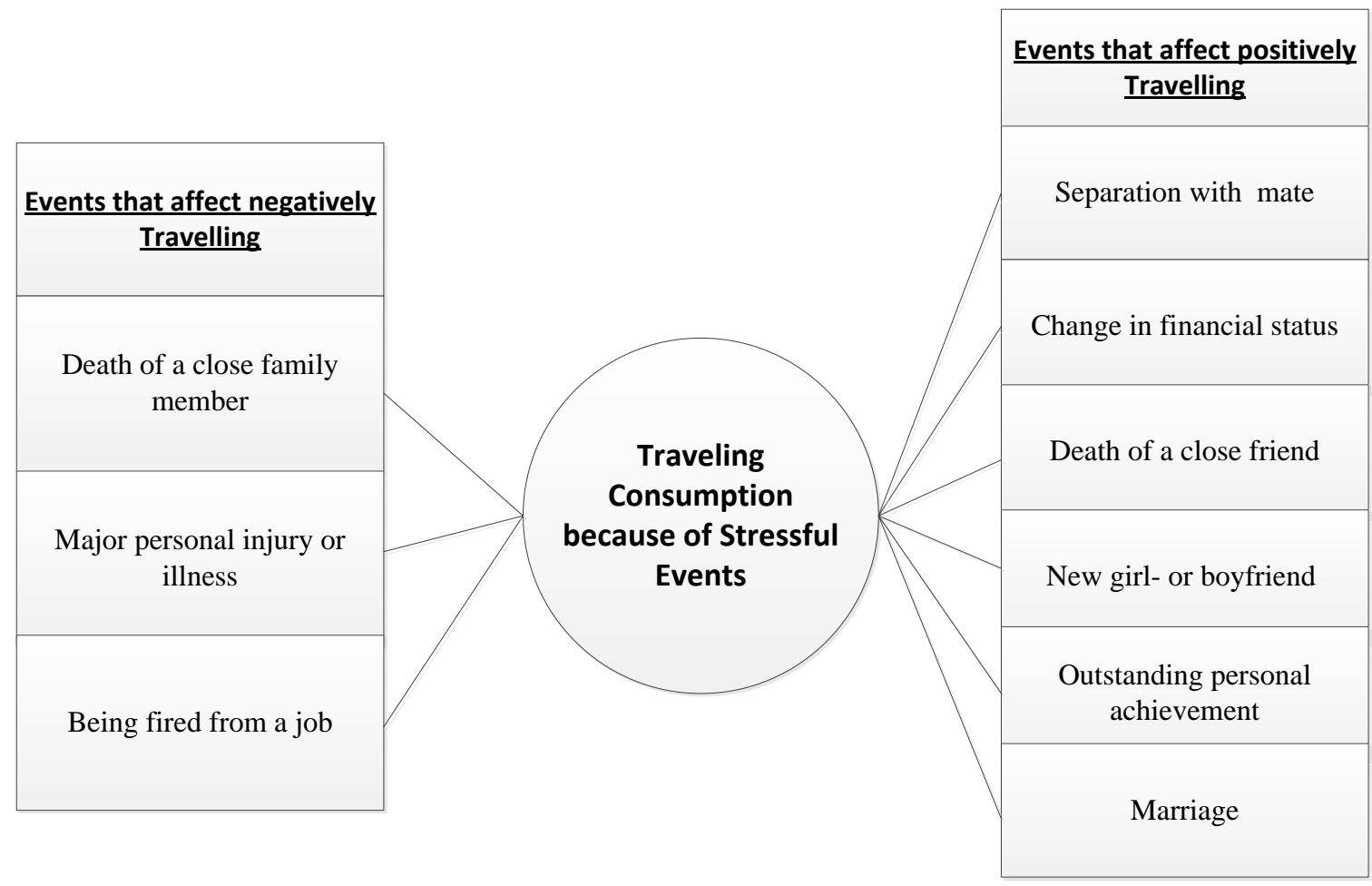

Figure 1: Traveling consumption related to stressful events

affect tourism consumption. Another important event is "Major personal injury or illness". When this happens they spend more money on doctors, communicating with friends and family or even alcohol. At the same time they spent less on travelling, alcohol, cigarettes and driving. "Separation with mate" affects positively travelling consumption, alcohol, cigarettes and entertainment expenses. It decreases consumption of super market and communication. Other stress full event which affect positive travelling consumption are a death of a close friend, a new girl-boyfriend, outstanding personal achievement and a marriage Figure. As we said before the main events that affect negatively travelling are death of a close family member, major personal injuries or illness and being fired from a job.

\section{Conclusions}

$80.8 \%$ of the students stated that the event "Death of a close family member" is the most important (total score: 20200) readjustment factor of their mental balance by causing stress to them. During its appearances the products consumed are Cigarettes, Alcohol,Tissues Inland Revenue, land registry, Municipality, Churches, I do not consume/no product, seat in for a time interval, Flowers, Hoop of funeral while Food is a relative choice which sometimes the students avoid and other times they adopt. Upon the appearance of the event the students' consumption of the amusement, recreation and travel services is reduced. The next most important event that $65.4 \%$ of the students note is the event "Pregnancy" (total score: 12900). It is characteristic here that the products Smoking and Alcohol are not consumed since the baby and mother's health during the pregnancy come first. Food in this case is a relevant choice while clothing is in this case a consuming element that supports the adjustment procedure of the mother and the father obviously due to the need for purchasing baby items, but pregnancy items as well. Third event in terms of importance (total score: 11500$)$ which gathered $42.3 \%$ of the students is the event "Major personal injury or illness". Alcohol is a relevant choice while there is a tendency in the reduction of Cigarettes, 
Food and Travels. Medical care and rehabilitation services, telecommunications, books and DVDs are consumption elements during recuperation. According to the students the remaining 12 important events of readjustment and stress inducement are in terms of hierarchy the following, "Separation with mate" (total score: 9650), "Change in financial status" (8650), "Increased workload at school/university" (8150), "Being fired from a job" (7720), "Death of a close friend" (7150), "New girl- or boyfriend" (6500), "Outstanding personal achievement" (5500), "Jail term" (5100), "Marriage" (4900), "Divorce between parents" (4500), "Failing an important course" (3370) and "Sex problems" (3300). In some events the products present a relevant consuming character like Alcohol in case 6 "Increased workload at school/university" or Candies in case 9 of table 2 .

In the cases where the products are classified and analysed by occurrence or event of appearance. Marketing people can benefit from the procedure of matching thematic events with the product categories, and suggest to their communicative strategy a more realistic strategy of approaching consumer groups which in this case were students. For instance, in an advertising approach which uses a thematic that includes one of the above important events of readjustment and stress it would be beneficial to emphasize the product that contributes to the negotiation and management of the stress tense by the consumers. Neutral goods can contribute through the correct presentation of their contribution (emotional and rational value for the consumer) to the reinforcement of the tense management, to the reduction of stress caused by the consumption of goods and to the consumer's self-confidence.

The present research of the readjustment scale can be supported by other segmentation researches that support the demographic differentiation of the people being questioned and the correspondence or association of the products with these characteristics. In addition, it should be noted that the small sample and the qualitative exploration cannot allow the generalization of the results in level of population.

\section{References}

Anil, M., Moschis, G., \& Euehun, L. (1999). Stress and consumer behavior: Coping strategies of older adults. Journal of Marketing Practice: Applied Marketing Science, 5(6/7/8), 233 - 247.

Blackwell, R. D., Miniard, P. W., \& Engel, J. F. (2006). Consumer behavior. Mason: Thomson.

Blasco-Fontecilla, H., Delgado-Gomez, D., Ruiz-Hernandez, D., Aguado, D., BacaGarcia, E., \& Lopez-Castroman, J. (2012). Combining scales to assess suicide risk. Journal of Psychiatric Research, 46(10), 1272-1277.

Cohen, S., Kamarck, T., \& R., M. (1983). A global measure of perceived stress. Journal of Health and Social Behavior, 24, 385-396.

Delgado-Gomez, D., Blasco-Fontecilla, H., Sukno, F., Socorro Ramos-Plasencia, M., \& Baca-Garcia, E. (2012). Suicide attempters classification: Toward predictive models of suicidal behavior. Neurocomputing, 92(0), 3-8.

Diniz, D. H. M. P., Schor, N., \& Blay, S. L. (2006). Stressful Life Events and Painful Recurrent Colic of Renal Lithiasis. The Journal of Urology, 176(6), 2483-2487.

Duhachek, A. (2005). Coping: A multidimensional, hierarchical framework of responses to stressful consumption episodes. Journal of Consumer Research, 332, 41-53.

Ellenberg, U., Setiawan, A. N., Cree, A., Houston, D. M., \& Seddon, P. J. (2007). Elevated hormonal stress response and reduced reproductive output in Yelloweyed penguins exposed to unregulated tourism. General and Comparative Endocrinology, 152(1), 54-63.

Fotiadis, A., Huan, T.-C., \& Costantino, C. (2013). An analysis of visitor behaviour using time blocks: the case of E-Da theme park, Kaohsiung, Taiwan. Paper presented at the The 3rd Advances in Hospitality and Tourism Marketing \& Management Conference, The Grand Hotel, Taipei, Taiwan.

Fotiadis, A., \& Vassiliadis, C. (2010). Rural tourism service quality in Greece. e- 
Can stressful events affect our tourism consumption? Empirical results of preliminary focus group analysis to student groups in Greece with the use of a life stress inventory model.

Review of Tourism Research (eRTR), 8(4), 69-84.

Fotiadis, A., Vassiliadis, C., \& Piper, L. (2013). Measuring Dimensions of Business Effectiveness in Greek Rural Tourism Areas. Journal of Hospitality Marketing \& Management, 1-28.

Fotiadis, A., Vassiliadis, C., \& Rekleitis, P. (2013). The constraints and benefits of sustainable development: a case study based on the perceptions of small hotel entrepreneurs in Greece. Anatolia: An International Journal of Tourism and Hospitality Research, 24(2), 144-161.

Fouquereau, E., Fernandez, A., Muller, E., \& Sorum, P. (2003). Stress and the urge to drink. Addictive Behaviors, 28, 669685.

Gibson, B. S. (1984). The convergence of Kuhn and cognitive psychology. New ldeas in Psychology, 2(3), 211-221.

Haatainen, K., Tanskanen, A., Kylma, J., Antikainen, R., Hintikka, J., Honkalampi, K.,Koivumaa-Honkanen, H., Viinamaki, H. (2003). Life events are important in the course of hopelessness - a 2-year follow-up study in a general population. Social Psychiatry and Psychiatric Epidemiology, 38, 436-441.

Hawkins, D. I., Best, R., \& Coney, K. (2001). Consumer Behavior: Building Marketing Strategy. Boston: Irwin McGraw-Hill.

Holmes, T. H., \& Rahe, R. H. (1967). The Social Readjustment Rating Scale. Journal of Psycosomatic Research, 11 , 213-218.

Houge Mackenzie, S., \& Kerr, J. H. (2013). Stress and emotions at work: An adventure tourism guide's experiences. Tourism Management, 36, 3-14.

Kamenidou, I., Mamalis, S., \& Priporas, C. (2009). Measuring destination image and consumer choice criteria. The case of Mykonos island. TOURISMOS: An International Multidisciplinary Journal of Tourism, 4(3), 67-79.

Kamenidou, I., \& Priporas, C. (2010). Factors predicting consumers' knowledge of spirulina health benefits. Journal of Food, Agriculture \& Environment, 8(1), 16-20.
Law, J., Pearce, P. L., \& Woods, B. A. (1995). Stress and coping in tourist attraction employees. Tourism Management, 16(4), 277-284.

Maréchal, L., Semple, S., Majolo, B., Qarro, M., Heistermann, M., \& MacLarnon, A. (2011). Impacts of tourism on anxiety and physiological stress levels in wild male Barbary macaques. Biological Conservation, 144(9), 2188-2193.

Mick, D. G., \& Fournier, S. (1998). Paradoxes of technology: Consumer cognizance, emotions, and coping strategies. Journal of Consumer Research, 25, 123-143.

Moschis, G. (2007). Stress and consumer behavior. Academy of Marketing Science, 35(3), 430-444.

Mullen, K., \& Gerald, C. (1981). Health Awareness Through Discovery. Minneapolis: Burgess Publishing Company.

Narayan, P. K., \& Prasad, A. (2008). Examining the Behaviour of Visitor Arrivals to Australia from Twenty Different Countries: An Application of Panel Unit Root Tests. Economic Papers: A journal of applied economics and policy, 27(3), 265-271.

Ngai, F.-W., \& Chan, S. W.-C. (2011). Psychosocial factors and maternal wellbeing: An exploratory path analysis. International Journal of Nursing Studies, 48(6), 725-731.

Reis, H. T. (2001). Social Psychology. In Elsevier Ltd (Ed.), International Encyclopedia of the Social \& Behavioral Sciences (pp. 14402-14405).

Romero, L. M., \& Wikelski, M. (2002). Exposure to tourism reduces stressinduced corticosterone levels in Galápagos marine iguanas. Biological Conservation, 108(3), 371-374.

Statt, D. (1997). Understanding the Consumer: A psychological Approach. Basingstoke: Macmillan.

Vassiliadis, C., Priporas, C., \& Andronikidis, A. (2013). An analysis of visitor behaviour using time blocks: A study of ski destinations in Greece. Tourism Management, 34, 61-70. 